\section{P134 EVALUATION OF LEPTIN LEVEL IN THE BLOOD SERUM IN CHILDREN AT AN EARLY AGE}

${ }^{1}$ Tetiana Chekotun*, 'Nadia Tokarchuk, 'Yulia Vyzhga, ${ }^{2}$ Ludmila Starynets. 'National Pirogov Memorial Medical University, Vinnytsya, Ukraine; ${ }^{2}$ Vinnytsya regional children's hospital, Vinnytsya, Ukraine

10.1136/archdischild-2019-epa.489

Actuality of the problem It is known that obesity starts in early childhood, when the foundations of eating behaviour and metabolic processes are formed in the organism.

Objective To investigate leptin level in the blood serum in children of an early age with excessive body mass (EBM) and obesity.

Patients and methods We have conducted a complex examination of 120 children of an early age at risk of developing an EBM, EBM, obesity. The examined children were divided into groups according to the results of evaluation of physical development: the $1^{\text {st }}$ group included children at risk of developing EBM (38 children $(31,6 \%)$; the $2^{\text {nd }}$ group included children with EBM (42 children $(35,0 \%)$; the $3^{\text {rd }}$ group included children suffering from obesity (40 children $(33,4 \%)$.

Results We have discovered a reliable elevation of leptin level in children suffering from EBM and obesity $(7,83 \pm 0,76 \mathrm{ng} / \mathrm{ml}$ and $21,6 \pm 4,60 \mathrm{ng} / \mathrm{ml}$ respectively) in comparison with the indicators in children at risk of developing EBM $(4,47 \pm 0,25$ $\mathrm{ng} / \mathrm{ml})$ and in children in the control group $(2,90 \pm 0,21 \mathrm{ng} /$ $\mathrm{ml}),(\mathrm{p}<0,05)$.

Spetial attention was given to the reliable difference between the values of leptin levels in the examined children depending on their sex. Thus, in girls of the main group the level of leptin was reliably higher if compared to the leptin level in boys, $(\mathrm{p}<0,05)$.

In order to analyze the obtained results we studied the correlation between the values of body mass index and the level of leptin in the examined children. As a result of the conducted study we investigate sitive correlation between leptin and body mass index $(\mathrm{r}=0,35 ; \mathrm{p}<0,05)$ in children at risk of developing EBM, in children having $\operatorname{EBM~}(r=0,4 ; p<0,05)$ and in children suffering from obesity $(r=0,57 ; p<0,05)$.

Conclusions It has been established that the level of leptin in children of an early age depends on the body mass and sex of the children. Thus, children with obesity have a reliably higher level of hormone in comparison to the children with excessive body mass. It has been found that the level of leptin in girls is reliably higher if compared to the level of leptin in boys.

The role of leptin level in the development of obesity in children of an early age is confirmed by close correlation with body mass index. The elevated level of leptin in children of an early age at risk of developing EBM and suffering from EBM is a possible predictor of obesity development.

\section{P135 COMPARATIVE CHARACTERISTICS OF THE PARAMETERS OF THE PHYSICAL DEVELOPMENT IN CHILDREN KHANTY PEOPLE OF MIDDLE PRIOBYE}

Olga Baitrak*, Vitaly Meshcheryakov. Surgut State University, Surgut, Russian Federation

10.1136/archdischild-2019-epa.490

The goal of the work is to develop norms for the physical development of ethnic Khanty children aged $0-17$ years and compare them with WHO data and the population of the Middle $\mathrm{Ob}$ region. The anthropometry of ethnic Khants to children aged $0-17$ years of the 1-2st group of health was conducted. Formed centile tables of parameters of physical development.

Individual and comprehensive assessment of health status is impossible without focusing on regulatory indicators. To this end, at present, in health organizations, the assessment of the state of children's health is carried out using indicators developed in a cohort of children and adolescents living in a remote area from the place of residence. The transition to the standards of the World Health Organization will unify the methodology for assessing the physical development of children and adolescents, make the results obtained at different times, in different countries and regions of the world, comparable.

Materials and methods An anthropometry of 13140 children and adolescents of entic Khanty born in the Khanty-Mansiysk Autonomous Okrug-Ugra of children and adolescents aged 0 17 years of the 1-2 nd health groups during medical examinations in schools and copying of outpatient cards of children's polyclinics of Surgut was made. The obtained results were subjected to mathematical processing using a nonparametric method for determining the cut-off points of the 3 , $10,25,75,90$, and 97 th percentiles of height, body weight, head circumference, chest, and the derived index - body mass index (BMI).

The use of non-regional norms leads to overdiagnosis of excess body weight in the elderly in an alien population, as well as overdiagnosis of nanism and hypodiagnosis of obesity in ethnic Khanty.

\section{Conclusions}

1. When developing standards and assessing the physical development of children and adolescents, it is necessary to take into account the child's territory of residence.

2. It is necessary to create regional standards of centile tables for the evaluation of height and weight indicators.

3. The described results of the study suggest that the use of standards of height, weight without taking into account the peculiarities of living in the North, may be the cause of underdiagnosis of obesity in ethnic Khanty, overdiagnosis of nanism

The established features of the physical development standards of the Khanty determine the need for their use for a more objective assessment of the health status of these representatives of IMs.

\section{P136 PREVENTION OF FOETAL ALCOHOL SPECTRUM DISORDERS - THE ROLE OF THE PAEDIATRICIAN}

Mary T OMahony*. Department of Public Health HSE-S, Cork, Ireland

\subsection{6/archdischild-2019-epa.491}

It is estimated that about 600 Irish babies are born each year with Foetal Alcohol Syndrome (FAS), and that over 40,000 Irish persons live with the condition. Foetal Alcohol Spectrum Disorders (FASD) including FAS are a consequence of alcohol induced brain damage which is permanent and associated with physical, mental, educational, social, behavioural difficulties. 'Children with FASD fill our Foster Care places. Adults with 